\title{
Zeldzame aandoeningen in klinisch genetisch perspectief
}

Citation for published version (APA):

Schrander-Stumpel, C. T. R. M. (2003). Zeldzame aandoeningen in klinisch genetisch perspectief. Maastricht University. https://doi.org/10.26481/spe.20030620cs

Document status and date:

Published: 20/06/2003

DOI:

$10.26481 /$ spe.20030620cs

Document Version:

Publisher's PDF, also known as Version of record

\section{Please check the document version of this publication:}

- A submitted manuscript is the version of the article upon submission and before peer-review. There can be important differences between the submitted version and the official published version of record.

People interested in the research are advised to contact the author for the final version of the publication, or visit the DOI to the publisher's website.

- The final author version and the galley proof are versions of the publication after peer review.

- The final published version features the final layout of the paper including the volume, issue and page numbers.

Link to publication

\footnotetext{
General rights rights.

- You may freely distribute the URL identifying the publication in the public portal. please follow below link for the End User Agreement:

www.umlib.nl/taverne-license

Take down policy

If you believe that this document breaches copyright please contact us at:

repository@maastrichtuniversity.nl

providing details and we will investigate your claim.
}

Copyright and moral rights for the publications made accessible in the public portal are retained by the authors and/or other copyright owners and it is a condition of accessing publications that users recognise and abide by the legal requirements associated with these

- Users may download and print one copy of any publication from the public portal for the purpose of private study or research.

- You may not further distribute the material or use it for any profit-making activity or commercial gain

If the publication is distributed under the terms of Article $25 \mathrm{fa}$ of the Dutch Copyright Act, indicated by the "Taverne" license above, 


\section{Zeldzame aandoeningen in}

klinisch genetisch perspectief 


\section{Collotion}

Basicontwerp en realisatie: Unigrophic, Universiteit Maastricht

Fototorafe anslag: Francis van der Lubbe

Touldoting bij de iflustratie op de vonizide:

ASPASIA van Miletus kefde van ajo tot 410 woor Christus. Zis sitond te boek ais courtisane maar de geschiedschrijwing hegft heit beeld gecorrigeerd want 2 il was in feite de lerares van 5 acrotes En de politiek adviseur wan pericles. Haor nacam is verbonden aan het stimuleringsprogramma wan NWO (Nederlands Wetenschappellyk onderzoek) en de VSNU Verenging wan Samenwerkende Nederlandse Universiteiten) in samenwerking met OCEnW (Onderwijs, Cultwu en Wetenschap) en richt zich op wrouwen in de wetenschap: met name de stop won Universitair Docent (UD) noar Unversitair. Hoofd Docent (UHD) wordt in dit programma gestimuleerd. Een van deze 3 wroumen, terracotabeelden wit ca 400 woor Christus opgegraven in syracuse, ltallë, zou har kumnen verbeelden. Het middelste beeld is afkoming wit de prive werzanteding wan de overleden archeologe professor dr. A.N.Zadoks-josephus fitta wit Groningen.

$195 N 90-565+176 \cdot 2$

Alle rechtem woorbehoudem. Niets uit deze uitgowe mag worden verveetvoudigd, opgeslagen in een geautonatiseerd gegevensbestand of openboar gemalak, zonder woorafgoonde schnfte. bike toestemming wan de autsur of witgever. 


\section{Zeldzame aandoeningen} in klinisch genetisch perspectief

\section{Rede}

Uitgesproken bij de aanvaarding van het ambt van bijzonder hoogleraar Klinische Genetica in het bijzonder voor de syndroomdiagnostiek en specifieke ontwikkelingsstoornissen

op 20 juni 2003 te Maastricht

door

Dr.C.Th.R.M. Schrander-Stumpel

Universiteit Maastricht 
Zorgen hebben is de keerzijde van zorg geven. Uit: 1 is vrowwern wijs waren wan Marianme Fredrikson 


\section{Zeldzame aandoeningen in klinisch genetisch perspectief}

Meneer de rector magnificus, leden van het college van bestuur, geacht bestuur van de Vereniging Samenwerkende Ouder- en Patiëntenorganisaties, geacht bestuur van de Stichting Klinische Genetica Zuid Oost Nederland, hoogleraren en leden van deze universitaire gemeenschap, hoogleraren van andere universiteiten in binnen en buitenland, en voorts allen die deze plechtigheid met uw aanwezigheid vereert,

Dames en heren,

De genetica is een vakgebied met een zeldzaam boeiende inhoud. Van oudsher wordt een deel van het huidige vakgebied $\mathrm{klinische} \mathrm{geneti-}$ ca vooral beoefend door kinderartsen. Sinds mei 1987 is de klinische genetica in Nederland als medisch special isme door de MSRC erkend; de opleiding duurt 4 jaar. De klinische genetica heeft raakvlakken met vele andere medische specialismen, maar onderscheidt zich daar ook duidelijk van. Een klinisch geneticus behandelt erfelijkheidsvragen op elk terrein en is meer een specialist voor de famillie dan voor de individuele patiënt. In de jaren tachtig hadden erfelijkheidsvragen vooral te maken met het (gaan) krijgen van kinderen. In de negentiger jaren trad, met de groeiende diagnostische mogelijkheden van het DNA onderzoek, een verschuiving op naar vragen over de toekomstige eigen gezondheid: hoe groot is de kans op een later in het leven optredende ziekte?

Voorbeelden hier zijn de vragen over neurologische aandoeningen en: over kanker. Anno 2003 kent onze afdeling een aantal speerpunten zoals de syndroomdiagnostiek, neurologische ziekten, fertiliteit en speciaal pre-implantatie genetische diagnostiek en erfelijke hartziekten.

De klinische genetica is een academisch specialisme en de taken liggen op het terrein van patientenzorg, research en onderwijs. Patiéntenzorg en klinische research liggen in elkaars veriengde en komen in deze rede geregeld samen aan bod.

Als eerste vrouwelijke hoogleraar in de klinische genetica neem ik graag de gelegenheid om $\downarrow$ mee te nemen langs het vakgebied, waarbij ik me vooral beperk tot de inhoud van de leerstoel: de syndroomdiagnostiek en specifieke ontwikkelingsstoornissen. Ik zal w een korte histo. 
rische terugblik geven, de huidige activiteiten beschrijwen en onze verdere plannen noemen, matar ook zal ik ingaan op enkele gerelateerde onderwerpen.

\section{Het recht op een diagnose}

Uitgangspunt bij de klinisch genetisch diagnostiek is dat elk individu met een ontwikkelingsstoornis, al dan niet gepaard gaande met structurele afwijkingen aan organen en/of aan het uiterlijk, recht heeft op een diagnose.

De specifieke expertise van de klinische genetica in de diagnostiek bij kinderen en volwassen met aangeboren afwijkingen en/of ontwikkelingsstoornissen ligt op het terrein van de syndroomdiagnostiek. Een syndroom is een herkenbaar patroon van multiple congenitale afwijkingen en (vaak) mentale retardatie. De unieke combinatie van kenmerken maakt een onderscheid mogelijk van ander patranen. Bij het lichamelijk onderzoek wordt speciaal gelet op zogenaamde dysmorfe kenmerken. De term "dysmorfologie", stalat voor het beschrijven van uiterlijke alfwijkingen in de lichaamsstructuur, ontstaan voor de geboorte. In een poging tot standaardiseren wordt vele lichaamsmaten genomen en in percentlelcurven uitgezet ( Hall et al, 1989). Centimeter en camera behoren tot het standaardgereedschap van de dysmorfoloog (Chudley, 2003). Naast de klinische kenmerken is de lichaamshouding, het bewegingspatroon, het niveau van functioneren, en het gedragsprofiel (zie verder) van belang om een syndroomdiagnose te kunnen stellen. Een jong kind met het fragiele $X$ syndroom wordt eerder op ontwikkeling en gedrag herkend dan aan zijn uiteriijk. Ook het beloop in de tijd is van belang in de klinische genetica: de klinische maten en de dysmorfie kunnen sterk kunnen veranderen in de tijd. Het jeugdalbum van een volwassen verstandelijk gehandicapte persoon kan doorslaggevend zijn voor de klinische syndroomherkenning.

Eerst konden we in de genetica wooral klinisch kijken: bij een beperkt percentage van de personen met een ontwikkelingsstoornis werd een oorzakelijke diagnose gesteld: dit was in ongeveer de helft van de gevallen een trisomie 21 ofwel Down syndroom en in enkele gevallen een zeldzame monogene aandoening. Dit was de situatie tot ongeveer eind jaren tachtig begin jaren negentig.

Inmiddels zijn ruim vierhonderd chromosoomafwijkingen bekend en zijn er meer dan vierduizend syndramen beschreven (zie o.a. Fryns, 1986). Op ellk chromosoom zijn genen bekend die, in geval van een muta- 
tie, een ziekte of aandoening kunnen weroorzaken. Het x-chromosoom neemt een bijzondere plaats in, ondat op dit chromosoom vele genen figgen die met intelligentie te maken hebben. Mutaties in deze genen verklaren het overschot aan mannen in de groep van mensen met een verstandelijke handicap. Het fragiele $X$ syndroom is de meest frequente aandoening in deze groep. Stap voor stap worden andere X-gebonden genen ontdekt en ontrafeld (bijvoorbeeld Frints, 2002).

Vanaf de negentiger jaren konden we niet alleen kijken naar de medische kenmerken ofwel het phenotype, maar ook meer onderzoek doen naar de genetische aanleg van een perscon ofwel het genotype. Zo kon bijvoorbeeld de betekenis van nieuw ('de novo") bij een persoon ontstane chromosoomafwijking zoals een translocatie verder worden ontraw feld. In de jaren negentig kwamen mogelijkheden van DNA anderzoek zoals koppelingsanalyse, mutatie analyse van steeds meer genen, en de aanpak via kandidaat-genen. De toepassing van muismodellen voor aandoeningen die zeldzaam zijn bij de mens is een belangrijk middel om tot verder begrip te komen.

Het zien van een patiënt en het aansturen van het genetische laboratorium is onlosmakelijk met elkaar verbonden om tot een optimaal resul. taat te komen. De klinische genetica als specialisme is niet los te koppelen van het academisch klinisch genetisch centrum. Het stellen van een oorzakellijke diagnose is een multidisciplinair gebeuren, meestal binnen het eigen klinisch genetisch centrum uitgevoerd en gericht ap de persoon zelf en zijn of haar familie.

Anno 2003 is de tijd aangebroken van de 'multigenen': aandoeningen die veroorzaakt worden door mutaties in meerdere genen, c.q. door interactie van verschillende genen met elkaar.

In de catalogus van mendeliaanse aandoeningen, inmiddels in vae druk verschenen, on-line beschikbaar en opgesteld door de internist-geneticus Victor Mckusick staan nu ongeveer 10.000 aandoeningen gerubri ceerd (McKusick, 1998; OMIM online website), In het Human Genome Project is vastgesteld dat het menselijk genoom ruim 30.000 genen bevat. Dit betekent dat interactie van genen een belangrijk gegeven moet zijn en dat dit een van de belangrijke richtingen voor verdere rese. arch is. Aspecifieke familiaire verstandelijke handicaps en autisme zijn daar voorbeeiden van. Deze laatste vormen van diagnostiek vereisen veelal internationale samenwerking en zijn vaak in zogenaamde consortia georganiseerd. 


\section{Het belang van een diagnose}

Waarom is het zo belangrijk om tot een syndroomdiagnose te komen? Een aantal redenen: ten eerste is duidelijkheid te geven aan de ouders/verzorgers over de naam van de aandoening en zo mogelijk ook over de oorzaak. De persoon met de syndroomdiagnose kan nu optimaal gevolgd en begeleid worden vanuit de kennis die over het bepaalde syndroom bestaat: preventief management. Vergelijk is mogelijk met andere patiënten en kennis over de vele aspecten van een syndroom kan gebundeld worden; tevens kunnen ouders en familieleden elkaar steum nen via lotgenotencontact en/of formele netwerken. Wetenschappelijk onderzoek is pas mogelijk na een goede klinische afbakening. Het beloop in de tijd, vaak een wan de grootste zorgen van ouders van een jong kind met een klinisch genetische diagnose, kan alleen duidelijk worden door follow up onderzoek te doen, liefst in multidisciplinair verband. Ouders hebben vaak meer vragen over het te haten ontwikkelingsniveau en het gedrag vam hun kind dan over cle medische diagnose. Onderzoek naar de oorzalak is belangrijk: veel kan geleerd worden als een mutatie in een bepaald gen een bepaald syndroom blijkt te veroorzaken. Gentherapie, waarop getroffen families natuurlijk hopen na de ontdekking van mutaties in een gen, is een belangrijk nieuw aandachtsgebied. Samenwerking tussen de academische wereld, de industrie en de ouderverenigingen biedt de kans om prioriteiten te stellen en om gericht mogelijkheden tot therapie te ontwikkelen.

\section{Klinische genetica en kinderwens}

Een paar met kinderwens en erfelijkheidsvragen gaat in principe naar de huisarts en wordt verwezen als de huisarts de wraag niet kan beantwoorden. Het paar heeft bijwoorbeeld een kind (of een familielid) met aangeboren afwijkingen en/of een vertraagde ontwikkeling en wil de kans op herhaling in een volgende zwangerschap weten. Deze vraag is pas te beantwoorden als er een diagnose, een oorzaak voor de medische problemen bekend is. Als er een verhoogd risico bestaat, wat zijn dan de handelingsopties? Is er een prenatale testmogelijkheid beschikbaar? De diagnostiek bij kinderen met aangeboren afwijkingen en ontwikkelingsstoornissen is een belangrijk terrein van de klinisch geneticus. Het begrip kinderen wordt ruim geinterpreteerd, want ook een overleden foetus met aangeboren afwijkingen en ook een wolwassene met een verstandelijk handicap, kunnen de aanleiding voor erfelijkheidsvra- 
gen in de famille zijn. De klinisch geneticus is niet aan een leeftjd gebonden en is vaak een familiedokter voor de genetische vragen.

Een voorbeeld: De ouders van een jonge vrouw, Colette van 34 jaar oud destijds, vroegen of de verstandelijke handicap erfelijk kon zijn woor de toekomstige kinderen van haar zuster. Aanleiding voor de vraag was het huwelijk en de komende kinderwens van deze zuster. Vroeger was bij Colette al eens chromosomenonderzoek gedaan met normale resultaten. Nu werd Colette opgezocht in het instituut waar zij woont, de medische gegevens van wroeger en nu werden verzameld en bestudeerd en zij werd klinisch onderzocht. Zij is een kleine vrouw met een kleine schedelomvang. Met vooral ook de foto's uit het familie album werd de klinische diagnose van $4 \mathrm{p}$ - syndroom gesteld. Opnieuw werd chromosomenonderzoek ingezet met wederom, door de microscoop, normale resultaten. Vanwege de klinische diagnose werd aanvullend cytogenetisch onderzoek gevraagd en nu werd met 'in situ hybridysatie' (FISH) een kleine deletie van $4 \mathrm{p}$ aangetoond. Deze delet le was nieuw bij Colette ontstaan en de ouders konden gerustgesteld worden over het herhalingsrico.

\section{Raakvlak klinische genetica en kindergeneeskunde}

In de diagnostiek en follow up bij kinderen met aangeboren afwijkingen en ontwikkelingsstoornissen ligt het raakvlak met een aantal andere specialismen, vooral kindergeneeskunde en kinderneurologie woor de hand. In Nederland is een aantal kinderartsen nauw betrokken (geweest) bij de start van de klinische genetica als nieuw medisch specialisme; zelf ben ik daar ook een voorbeeld van. Al tijdens mijn opleiding tot kinderarts in het Onze Lieve Vrouwe Gasthuis in Amsterdam kwam ik in aanraking met kinderen met een syndroomdiagnose of een vraag daarnaar. De in 2002 overleden klinisch geneticus Jan Bijlsma, een wan de nestoren van de Nederlands klinische genetica, kwam daar als consulent en betrok mij bij zijn werk. Mijn eerste genetisch publicatie was met hem en ging over het Aarskog syndroom (Schrander-Stumpel et al, 1985). In het raakvlak van diagnostiek en follow up kunnen kinderartsen en klinisch genetici elkaar aanwullen, van elkaar leren en voor cle ouders zo efficiënt mogelijk goede zorg bieden. Landelijk is de samenwerking op dit terrein zichtbaar in de sectie Erfelijke en Aangeboren Afwijkingen wan de Nederlandse Vereniging woor Kinderartsen (NVK). Door een commissie vanuit de NVK en de Vereniging Klinische Genetica Nederland 
(VKGN) werden in 2002 richtlijnen aangeboden aan de NVK voor een vervolgopleiding Klinische Genetica voor kinderartsen.

\section{Klinische genetica in Maastricht}

In 1981 vond de oprichting van de Stichting Klinische Genetica Limburg plaats, naar voorbeeld van de stichting in Rotterdam. De klinisch genetische patiëntenzorg (syndroomdiagnostiek) ging van start met mw. L. Siderius vanuit de Kindergeneeskunde, aanvankelijk met ondersteuning wan de in 1985 overleden kinderarts B. ter Haar with Nijmegen. En cytogenetisch laboratorium was al in Maastricht aanwezig. In 1983 is de Stichting Klinische Genetica Limburg officiëel van start gegaan met het aantreden van Prof.dr.J.Geraedts als directeur. Datzelfde jaar kwam G. Hamers als hoofd van de cytogenetica in dienst wanuit instituut voor werstandelijk gehandicapten Maria Roepaan" (het huidige "Vizier") in Ottersum. Dr. L. Spaapen werd aangetrokken voor het biochemisch genetisch onderzoek. DNA diagnostiek ging in Maastricht pas in 1995 van start en staat nu onder leiding van dr. B. Smeets. Op I Juli 1984 startte dr. C. de Die-5mulders haar carrière in de klinische genetica, ook met steun van B. ter Haar en met dr. B. Hamel, beide collegae te Nijmegen. In 1985 ging mw. L. Siderius naar elders en kwam ik als kinderarts en meteen als hoofd van de klinische "groep" de afdeling versterken. Op initiatief van professor $d r$. J.Geraedts werd contact gelegd met professor dr.J.-P. Fryns in het centrum voor Menselijke Erfelijkheid te Leuven. Daar werd ik bijgeschoold in de klinische genetica, vooral in de syndroomdiagnostiek en het chromosomenonderzoek: een formele opleiding bestond nog niet. DNA onderzoek was voorzichtig in aantocht, in de tachtiger jaren vooral koppelingsanalyse bij enkele monogene aandoeningen zoals de spierdystrofie wan Duchenne en hemofilie. De afdeling heeft een ongekende groei meegemaakt; dit is inherent aan de beweging in de tijd, aan het feit dat het genetische centrum te Maastricht het jongste centrum was en er nog veel in te halen was en niet in de laatste plaats aan de in 1997/8 uitbreiding van het werkgebied met de regio Zuidoost Brabant door een fusie wan de SKGL met de stichting Erfelijkheidsonderzoek Noord Brabant (SENB) tot de Stichting Klinische Genetica Zuid Oost Nederland (SKCZON). De klinische genetica heeft zich een vaste plaats werworven naast de andere academische specialismen. Recent is een start gemaakt met de integratie van onze afdeling in het academisch ziekenhuis Maastricht. Deze integratie kan bijdragen aan de verdergaande multidisciplinaire benadering en 
afstemming tussen de klinische genetica en de andere medische speciallismen (Planningsbesluit WWS, 2003).

\section{Syndroomdiagnostiek in Maastricht}

De aanpak rondom de syndroomdiagnostiek is vanaf mijn komst geinspireerd geweest door het Leuvens model: niet alleen medisch kijken maar ook naar de psychologische en kinderpsychiatrische aspecten en niet alleen nu kijken maar ook in de tijd volgen: alleen zo komen gegevens over het natuurlijk beloop beschikbaar. Dit laatste geldt voor de kinderen/volwassen met een bekende diagnose, maar ook woor hen met een niet bekende diagnose. Uitgangspunt hierbij is, zoals eerder genoemd, dat ieder individu met een ontwikkelingsstoornis recht heeft op een diagnose. Als u zich realiseert dat het met maximale inspanning bij $30-50 \%$ van de kinderen en volwassenen met aangeboren afwijkingen en/of een verstandelijke handicap nog niet mogelijk is am tot een oorzakelijke diagnose te komen (bijvoorbeeld Curry et al, 1997), dan begrijpt $u$ dat er nog veel werk te doen is.

Wij beogen een expert center te zijn voor vragen naar syndroomdiagnose en/of oorzaak van ontwikkelingsstoornissem. De aanpak is multidisciplinair, zowel binnen de eigen afdeling als daarbuiten. Binnen de eigen afdeling zijn er de spreekuren met medisch psycholoog professor dr. L.Curfs, kinder-en jeugdpsychiater dr. J.Steyaert, kinderarts/kinderneurolloog E.Smeets. Binnen het azM zijn op dit terrein spreekuren met de kinderarts, vooral dr. J.Schrander en met de kinderneurologen, vooral mw. B.Weber en professor dr. J.Vles, en met de kinderarts voor metabole ziekten dr. E.Rubio.Voorbeelden van multidisciplinaire poliklinieken zijn de recent gestarte neurofibromatose poli, de poli voor kinderen met een ontwikkelingsstoornis, de poli voor kinderen met een (wraag naar) specifiek syndroom of kinderen met een zeldzame chromosoomafwijking en de trisomie 21 poli. In diverse ziekenhuizen in de regio zijn spreekuren kindergeneeskunde/klinische genetica. In de instellingen voor mensen met een verstandelijke beperking wordt intensief samengewerkt met de Artsen voor Verstandelijk Gehandicapten (AVG). Kinderen/volwassenen met een specifieke diagnose worden als groep afgebakend. Per diagnosegroep worden de kinderen/wolwassenen gecontroleerd volgens de richtlijnen die bestaan (Wilson en Cooley, 2000; Cassidy en Allanson, 2001) of die we zelf wanuit de follow up gegevens opstellen (Schrander et al, 200n; Smeets en Schrander, 2003).

Deze aanpak wordt gecontinueerd en zal verder uitgebouwd worden. 


\section{Wie geeft de medische zorg aan mensen met een zeldzaam syndroom}

De kinderarts is in principe diegene die de medische zorg rondom het kind met een syndroomdiagnose organiseert en coördineert. De huisarts wou zeker ook een rol kunnen spelen. De kinderarts heeft een beperking in de tijd, want iemand met een volwassen kalenderleeftijd komt niet meer bij de kinderarts, ook al is de mentale leeftijd die van een kind. De overdracht van kinderarts naar andere medicus die de zorg overneemt is belangrijk en niet zonder risico van kwaliteitsverlies. in theorie geen probleem: er is sinds 2000 een nieuw specialisme erkend: dat wan Arts voor Verstandelijk Gehandicapten (AVG). De opleiding duurt 3 jaar; de Erasmus universiteit in Rotterdam is als landelijk opleidingsinstituut erkend. In halar oratie getiteld "Normale burgers, bijzondere patienten" zette professor dr. H.Evenhuis uiteen dat de medische zorg voor de mensen met een verstandelijke handicap beter kan (2000). Kennis is nodig over de te verwachten morbiditeit in deze groep en richtlijnen zijn nodig om deze mensen niet te kort te doen. Een AVG is verbonden aam een instelling voor mensen met een verstandelijke handicap en kan in consult gevraagd worden. Echter, met de verschuiving van wonen in een zorginstelling naar kleinschalige woonvormen in de wijk, komt steeds meer medische zorg bij de huisartsen te liggen, met kans op versnippering van ervaring en achteruitgang in de zorg. De huisarts naast de AVG biedt mogelijkheden maar kent ook valkuilen (Gruijters, 2000). Landelijk zijn veel initiatieven gaande om taken af te stemmen tussen instelling en huisartsen en zo de medische zorg zo goed mogelijk te waarborgen. Recent werd binnen deze universiteit een concept richtlijn opgesteld voor de medische zorgoverdracht van verstandelijk gehandicapten (zie Medisch Contact, 2003). In mijn visie kan ook de klinisch geneticus een rol hebben in de overdracht van kenmis: deze specialist is immers niet beperkt in de tijd, maar kan expertise over de vele zeldzame aandoeningen bundelen vam jonge tot oude leeftijd.

\section{Bundeling van expertise en kllinische research}

Probleem in de diagnostiek van de vele syndromen is dat de meeste zeldzaam zijn met een frequentie van voorkomen van 1:10.00o pasgeborenem of minder. Ruime klinische ervaring kan het stellen van een diagnose bespoedigen en bundeling van deze expertise is van grote meerwaarde voor de doelgroep: de gezinnen en famillies waarin het kind met een zeldzame afwijking geboren is en opgroeit. Door bundeling is 
klinische research mogeligk.

Als voorbeeld van onze research noem ik het Rett syndroom: een ernstige neurodegeneratieve aandoening die vooral bij meisjes voorkomt en weroorzaakt wordt door mutaties in het MECP2 gen "gelegen op chro" mosoom $\mathrm{Xq}_{2} 8$. Landelijk is via de federatie van ouderverenigingen een netwerk actief en internationaal is men toenemend georganiseerd. Vanuit onze afdeling wordt klinische kennis en ervaring met kinderarts/kinderneuroloog E. Smeets gebundeld en (inter)nationaal bekend gemaakt (Smeets et al, 2003). Bij deze aandoening is ook research over de genetische achtergrond gaande.

Ook bij syndromen die relatief bekend lijken, blijft follow up en bundeling van expertise belangrijk. Zo is over Prader-Willi syndroom vee bekend, maar relatief weinig over de specifiek problemen bij de ouder wordende persoon met dit syndroom. We weten dat mensen met Prader-Willi syndroom extreem dik worden als de diagnose niet tijdig wordt gesteld en als de aanpak rondom eten niet adequaat is. Een sterk overgewicht is een risico voor complicaties als hoge bloeddruk, suikerziekte en beperkt de levensduur; dit is natuurijk niet specifiek voor Prader-Willi syndroom maar geldt ook woor de algemene bevolking. Het relatief onverwacht zeer ernstig ziek zijn en soms overlijden van een jong en slank kind met Prader-Willi syndroom roept de vraag op of dit iets met het syndroom te maken heeft of niet (Schrander-Stumpel et al, 2003). Op zeer jonge leeftijd is ademhalingspierzwakte en een lucht. weginfectie een risicofactor die wel aan het syndroom gerelateerd kan worden.

De Prader-Willi verenigingen zijn een goed voorbeeld van hetgeen vanwit ouder-en patiënten netwerken in samenwerking met professionals bereikt kan worden.

Een laatste woorbeeld is het ongeveer 6 jar geleden opgerichte netwerk voor ouders van kinderen met het Kabuki syndroom. Dit nationale netwerk werd in Limburg opgericht en is inmiddels aangesloten bij vele Kabuki netwerken internationaal. Met stimulans vanuit dit netwerk kon een aantal studies verricht worden: een bundeling van alle medische gegevens met van daaruit richtlijnen voor preventief management (Schrander-Stumpel et al, 2003). Tevens een studie naar mogelijke kenmerkende ontwikkelings- of gedragsprofielen (Curfs et al, 2002) en een studie naar de taalkenmerken bij dit syndroom (Defloor et al, 2002). Een oorzaak van het kabuki syndroom is nog niet bekend. Ik verwacht dat dit 
een heterogene aandoening is, deels te verklaren door een kleine chromosoomafwijking, deels door een de novo dominante mutatie in het genoom. Deze latatste hypothese wordt ondersteund door een verhoogde vaderlijke leeftijd.

\section{Patiëntenverenigingen}

$U$ las al een paar keer de term oudernetwerk/patientenvereniging. Vanuit onze afdeling wordt met meerdere patiëntenverenigingen samengewerkt: voorbeelden zijn die voor mensen met neurofibromatose, met Rett syndroom, met Kabuki syndroom, met Prader-Willi syndroom, enzowoorts. De samenwerking tussen deze verenigingen en professionals in de gezondheidszorg is belangrijk maar ook enigszins complex. De rol van de professionals in de netwerken wordt vooral gezien als ondersteunend. Richtlijnen voor professiomals in dergelijke netwerken werden opgesteld door de Amerikaanse "Genetic Alliance", die in 2002 ruim 300 aangesloten verenigingen telde (zie website). Professionals en families kunnen veel van elkaar leren en in samenwerking tot fraaie onderzoeksresultaten komen. Recent werd een eerste studie gepubliceerd over de betrokkenheid vain professionals, wooral kinderartsen/klinisch genetici/dysmorfologen en leden vain de David Smith groep, in genetische ouder- en patiënten verenigingen (Lin et al, 2003). Bijna $90 \%$ was actief betrokken bij 2 of 3 verenigingen. Het ging zawel orn praktische ondersteuning, als ook om wetenschappelijk onderzoek. Dit is in lijn met onze eigen ervaring. Vooral rondom research zou een conflict van belangen kumnen ontstaan, gaf $65 \%$ van de respondenten aan. Onze eigen ervaring leert dat de verenigingen vooral zelf met vraag naar onderzoek naar de professionals komen en dat een en ander in goed overleg gebeurt.

De Federatie van Ouderverenigingen is een samenwerkingsverband van viff landelijke verenigingen van mensen met een verstandelijke handicap, hun ouders en verwanten.

Bij de VSOP, de Vereniging Samenwerkende Ouder- en Patientenorganisaties, betrokken bij erfelijkheidsvraagstukken, zijn 58 organisathes aangesloten. De VSOP wil door het beïnvloeden van beleid bevorderen dat de ontwikkelingen op het terrein van genetische kennis en medische biotechnologie, optimaal bijdragen aam welzijn en gezond heid, ook van toekomstige generaties (zie VSOP en de website). De volwaardige maatschappelijke positie van mensen met een erfelijke aandoening of afwijkende erfelijke aanleg staat daarbij centraal. Deze betrokkenheid is 
zichtbaar in de vele publicaties, manifesten en maatschappelijke debat. ten. Namens of mede mamens de VSOP zijn meerdere bijzondere ordinariaten klinische genetica ingesteld, waaronder deze leerstoel.

\section{Klinisch genetisch onderzoek en publiceren}

Het Humane Genoom Project heeft veel alandacht gekregen in de pers en hoop gegeven op verdere ontdekkingen en toepassingen. Deze hoop is terecht en er zijn belangrijke ontwikkelingen te signaleren. Aan de andere kant echter is er een soort van genohype ontstaan, met soms valse hoop voor investeerders zowel als patienten (Holzman, 1999). In de medisch genetische literatuur is toenemend een tweedeling zichtbaar: de kinische artikelen en de laboratoriumtechnische. Bij een toenemend aantal artikelen over DNA mutaties bij bepaalde zeldzame aandoeningen worden de klinische kenmerken van de patiënt(en) niet of nauwelijks meer beschreven. Evaluatie van dergelijke publicaties en praktische toepassing in de patièntenzorg wordt op deze manier onmogelijk gemaakt. Recent werd in twee internationalle tijdschriften een pleidooi gehouden om vooral klinische gegevens en (indien aan de orde) ook klinische foto's toe te voegen aan moleculaire artikelen die over patiénten gaan (Hall, 2003; Aylsworth et al, 2003; Carey, 2003). Cenoemde situatle wordt in de hand gewerkt door een werschill in waardering: publicaties over moleculair werk worden in academische zin hoger gewaardeerd dan publicaties over klinische observaties. De zogenaamde "Science Citation Index" van tijdschriften met veel moleculair werk is hoger dan die met wooral klinische beschrijvingen (ca 10 voor bijwoorbeeld het American Journal of Human Genetics versus ca 2 voor het American Journal of Medical Genetics)(zie website). Deze index is belangrijk: hoe hoger de index hoe belangrijker een publicatie woor de academische carrière. Mijn stelling uit 1995: "In de academische wereld worden patiëntenzorg en patièntgericht wetenschappelijk onderzoek ondergewaardeerd' is nog actueel. Bij het instellen van déze lleerstoel aan deze universiteit echter is van onderwaardering geen sprake. Deze leerstoel heeft een nadrukkelijk klinische taakstelling. Ik ben daar blij mee; deze opdracht doet recht aan het werk dat we op onze afdeling doen en geeft kansen woor verdere uitwerking en structurering.

Onze ervaringen in het klinisch onderzoek worden zo veel mogelijk opgeschreven en ter publicatie aangeboden. Doel daarbij is niet alleen om de academische carrières van de jonge collegae kansen te geven, 
maar ook om de ervaringen bekend te maken bij andere professionals en ouder/familienetwerken. Deze doelstellingen betekenen dat we niet alleen internationaal in tijdschriften met een zo hoog mogelijke wetenschappelijke 'citation index' publiceren, maar ook nationaal: ik verwijs naar de maandelijkse serie artikelen in Patient Care: vanaf maart 2000 tot heden zagen inmiddels 40 artikelen het licht met Hans de Nijs Bik. senior kinderarts, als vaste medeauteur. Ook de serie'van gen naar ziekte' in het Nederlands Tijdschrift voor Geneeskunde is een goed woorbeeld van nationaal werk (zie bijvoorbeeld Jonkman et al, 2003). In thaar rapport "The social impact of applied health research. Towards a quality assessment system" besteedt de Koninklijke Nederlandse Academie van Wetenschappen (KNAW) aandacht aan de maatschappelijke implicaties van medisch-wetenschappelijk onderzoek (2002). Het voorstel om de vertaalslag van wetenschap en kernis naar de populatie toe, vooral via de eerstelijns gezondheidszorg, nader te bezien en in termen wan kwaliteitsbeoordeling te beschrijven, is belangrijk en dit werd in het Nederlands Tijd schrift voor Geneeskunde onderstreept (van Weel, 2003). Ik hoop dat dit initiatief voortgang vindt: juist op het gebied van de genetica is de behoefte aan informatie en vertaling naar andere professionals en bevolking groot.

\section{Onderwijs in de klinische genetica}

Klinisch genetisch onderwijs speelt zich op vele terreinen af Om dicht bij de patientenzorg te blijven: we stimuleren ouders om zo veel mogelijk te leren over de aandoening van hun kind. Zij worden professionals en hebben een taak in de voorlichting. Vooral naar de soms vele betrokken dokters, naar psychosociale hulpverleners, naar school. Ook voorlichting aan de eigen familie is nodig. Wij helpen hen daar zo goed mogelijk bij door te praten, voorlichtingsmateriaal te geven en/of voor hen te maken, op het internet te wijzen (voorzover nog nodigl) en in ouder/lotgenotencontacten te bemiddelen.

In het nieuwe curriculum geneeskunde is genetica en met name klinische genetica een onderwerp dat vaker aan bod zou moeten komen. In het eerste jaar gelidt dat zeker, In blok 2.2 getiteld "Wens - kind - mens" is de klinische genetica goed vertegenwoordigd. Dit blok met blokcoördinatoren dr. C. de Die-Smulders, klinisch geneticus, en dr. M. van de Hoeven, neonatoloog, kreeg recent de studentenprijs voor het beste blok! Belangstelling is er bij de studenten wel: twee nieuwe keuzeblokken in het tweede jaar getiteld:"Erfelijke en aangeboren afwijkingen" en 
"Verstandig omgaan met beperkingen" waren op de intekeningsidatum al overboekt. In jaar 3 komt het vak summier aan de orde: in het blok 'abdomen' is een college gepland. Vanaf september $2003 \mathrm{krijgen} \mathrm{co-}$ assistenten kindergeneeskunde opdrachten om tijdens de stage uit te werken en er staat een nabespreking in de naweek geagendeerd. Het vierde studiejaar wordt momenteel ontworpen en wij zijn als capaciteitsgroep proactief doende. De co-assistenten komen bij ons voor een korte stage van 2 weken (nog het oude curriculum) of woor een wetenschapsstage van enkele maanden. Zij tonen zich vaak verrast door de boeiende inhoud van het vakgebied en de afwisselende ervaringen in de klinisch genetische patientenzorg.

Structureel zijn we betrokken bij de eigen opleiding, de huisartsenopleiding en de opleiding van de verloskundigen. Aan deze laatste twee beroepsgroepen kan het onderwijs nog sterk uitgebreid en verbeterd worden.

Nascholing klinische genetica aan huisartsen, verloskundigen en andere specialisten gebeurt al jaren lang ad hoc, wia refereeravonden die we zelf organiseren, via refereeravonden van het betreffende specialisme en via symposia/congressen. Sinds 2002 is een commissie van de VKGN actief om landelijke en liefst structurele nascholing klinische genetica aan te bieden aan andere beroepsgroepen.

\section{Academisch specialist zwaar belast}

De functie inhoud van de academische specialisten bestaat niet alleen uit patiëntenzorg, maar ook onderwijs, onderzoek, management en andere nationale en internationale taken eisen tijd en aandacht. Een mens en ook een academisch specialist kan echter niet alles tegelijk en kan ook niet alles even goed doen. Onder de titel "Dokter of doctor" schreef professor dr. Jvan Engelshoven in Medisch Contact een kritisch stuk (2002). Hij stelde de situatie aan de kaak dat medisch specialisten in de universitaire wereld vooral op hun wetenschappelijk output gewaardeerd en beoordeeld worden en dat kwaliteitscriteria voor hun andere werk, onderwijs en vooral ook patiëntenzorg, elgenlijk niet bestaan. Een vaste aanstelling zonder promotie is in principe niet meer aan de orde. Voor de artsen in opleiding tot specialist, die een academische carrière beogen is het ook niet makkelijk. Al is er tijd voor wetenschappelijk onderzoek de faciliteiten blijken gering en het aantal AGIO's dat wetenschappelijk onderzoek doet, neemt af (Verhoef, 2003). Hier liggen taken en kansen voor de raad van bestuur van het zlekenhuis, de 
decanen van de universiteit en het bestuur van $M U C H$. In Utrecht, het UMC (Utrecht Medisch Centrum), kunnen uitstekende prestaties op gebled van onderwijs of patientenzorg inmiddels ook een leerstoel opleveren (Lautenbag, 2002)

\section{Aandacht voor de vroww}

Zonder vrouwer draait de wereld niet. Ook in de klinische genetica zijn vrouwen belangrijk: als gebruiker van het specialisme en als professional. Als patiënt/cliënt/gebruiker hebben de vrouw en haar partner erfelijkheidsvragen en kinderwens. Bij behandeling van fertiliteitproblemen is de vrouw zwaarder belast, zwanger zijn is aan de wrouw, evenals het andergaan van prenatale diagnostiek en het krijgen van kinderen. Het zorgen voor de kinderen kan gedeeld worden, maar de vrouw blijft veelall het meest in de zorg betrokken: het is met name de vrouw die zorgt en die zich zorgen maakt. Ik citeer hier vrij de Zweedse schrijfster Marianne Fredrikksion uit haar werk: "Als vrouwen wijs waren".

\section{Vrouw en academische wereld}

Hoe draait de universitaire wereld om de vrouw heen? Het percentage vrouwen bij studenten geneeskunde is tegenwoordig 65-70, bij afgestudeerde artsen is dit percentage gedaald tot onder de 40 . Vrouwen doorlopen de studie gemiddeld wel vlotter en stromen gemiddeld een jaar sneller een vervolgopleiding in dan mannen (van der Velden et al, 2003). Bij promovendi is thet percentage vrouwen gedaald tot onder de 30. Van de universitair docenten (UD's) is $22 \%$ vrouw, van de universitair hoofddocenten (UHD's) 8\%. Het percentage vrouwelijke hoogleraren aan de faculteiten der geneeskunde bedraagt 3.3 (Takkenberg, 2003). Het aigemene percentage vrouwelijke hoogleraren in Nederland is ruim 6. Nederland staat hiermee op de een na laatste plaats in Europa (na lerland). In een recent sympasium georganiseerd door het landelijk net. werk vrouwelijke hoogleraren, getiteld "ledereen hoogleraar $\mathrm{m} / \mathrm{v}$. Hooglerarschap in de eenentwintigste eeuw" (2002), werd verslag gedaan van de historie maar voorall ook van de huidige activiteiten om wrouwen te ondersteunen en te stimuleren. Het ruim 275 leden tellende netwerk werd in 1993 opgericht en will middels allerlei initiatieven een evenredige vertegenwoordiging van vrouwen binnen de universitaire gemeenschap bevorderen. 
Een positieve tendens is zichtbaar, ondermeer door projecten als ASPASIA (Mediator, 2001), waarbij vooral de doorstroom van UD naar UHD gestimuleerd wordt, maar het gaat langzaam. In haar boek "Geleerde moeders" schetst Lies Wesseling (2001) hoe het moederschap in haar studie meestal geen reden is om minder te gaan werken of om geen hogere functie te willen bekleden. Zij ziet meer struikel blokken in de organisatiecultuur aan de top van de universiteit en in thet gegeven dat vrouwen de maatschappelijke waarde van hun werk belangrijker vinden dan hun mannelijke collega's. Vrouwen kiezen ook meer voor leuk werken, een op de mens gerichte omgeving, waar manmen meer naar status en salaris kijken.

In vakgebieden wäar kinderen en/of counseling belangrijk zijn, werken meer vrouwen. Dit is in de klinische genetica niet anders. Voor vrouwelijke professionals blijkt het vakgebied klinische genetica antrekkelijk. Eind 2002 was $66 \%$ van de klinisch genetici en $78 \%$ van de artsassistenten klinische genetica vrouw.

De Vereniging van Nederlandse Vrouwelijke artsen (VNVA, zie website) wil een bijdrage leveren aan de verbetering van de pasitie van vrouwelijke artsen en aan de verdere ontwikkeling van de genderspecifieke gezondheidszorg. Namens de VNVA is inmiddels een bijzonder hoogleraar Vrouwenstudies Geneeskunde benoemd in de persoon van professor dr. T. Lagro-Janssen. Zij benadrukte in haar oratie hoe belangrijk het is om in de geneeskunde rekening te houden met het man of vrouw zijn van de patiënt (1997). In de klinische genetica is mijns inziens overigens wel eens meer aandacht nodig voor de man als patiënt/cliënt!

Willen we naar een fiftyfifty verhouding toe op alle acadlemische niveaus? Mijns inziens is dat niet een doel op zich. Niet iedere academicus, man of vrouw, ambieert een universitaire carrière: dat moet gerespecteerd worden. Wat ik wel voorsta, is dat vrouwen en mannen die dat ambiëren, serieus genomen worden en gestimuleerd. Het structureel benoemen van vrouwen in benoemingscommissies en promotiecommissies biedt kansen om keuze van kandidaten mee te bepalen (De Angelis, 2000). Daarbij moet in geval van een vrouw respect bestaan voor een pauze gedurende de reproductieve fase en moet een tijdelijk verlaagde output van publicaties en projectaanvragen geaccepteerd worden. Een latere (door)start getuigt van motivatie en doorzettings. vermogen. De vrouwelijke specialisten op onze afdeling illustreren dat deze bewering juist is. Onze 3 speciallisten in opleiding zijn vrouw en ik heb alle vertrouwen in hun professionele toekomst. 


\section{Dankwoord}

Aan het eind van deze oratie neem ik graag de gelegenheid om een woord van dank uit te spreken aan de mensen die deze leerstoel en mijn bekleding ervam hebben mogellik gemaakt. Allereerst de VSOP en de SKCZON, die deze leerstoel mede mogeligk maakten. Hartelik dank aan VSOP directeur Cor Dosterwijk en voormalig directeur Ysbrand Poortman: ik ben niet de eerste bijzonder hoogleraar vanwege de VSOP en hopelijk ook niet de laatste. Dank voor jullie stimulans en aanwezig. heid hier: ik hoop de belangrijke samenwerking met de USOP nog lang door te kunnen zetten en jullie vertrouwen waar te maken.

Professor Geraedts, directeur van de SKGZON: beste Joep: jij hebt in 1985 voldoende vertrouwen gehad in een belangstellende kinderarts die geregeld bij je langs kwam met de vraag naar een baan in de klinische genetica, een specialisme dat nog niet bestond. Jouw woorstel om mijn bijscholing niet in Utrecht te doen, zoals ik eigenlijk al had geregeld, maar naar Leuven te gaan, was een gouden greep. Mijn ontmoeting met professor $d r$. J.P.Fryns dateert van 1985 toen we samen op orienterend gesprek naar Leuven gingen en het toenmalig diensthoofd professor dr. H. Vandenberghe en professor dr. J.P. Fryns ontmoeten. Ik dank je woor dit initiatief en voor de continue steun door de jaren heen.

Professor Fryns, Jean-Pierre, vanaf mijn aarzelende schreden in de klinische genetica heeft $u$ mij gestimuleerd en gesteund. Als Amsterdammer wist ik niets van België in het algemeen en Leuven in het bijzonder. Inmiddels weet ik dat wel en prijs ik me gelukkig met onze banden. De patientenzorg is onze drijfveer, het welzijn wan onze medewerkers een conditio sine qua non en fraaie publicaties en promoties zijn belangrijke zichtbare resultaten. De samenwerking tussen Maastricht en Leuven wat betreft de klinische genetica is een voorbeeld van een belangrijke euregionale samenwerking tussen twee universiteiten; yoor patienten en voor professionals is eenzelfde taalgebied een voordeel. Ik hoop de samenwerking tussen onze groepen nog lang te mogen meemaken.

De Universiteit Maastricht, geachte rector magnificus professor $\mathrm{dr}$. A. Nieuwenhuis Kruseman: ik dank u voor de instelling van deze bijzondere leerstoel en woor de positieve steun om mij op deze stoel te benoemen. 
Het college van toezicht van deze leerstoel onder leiding van professor dr. G. Kootstra: hartelijk dank voor de steun en het vertrouwen.

De vele studenten die onze afdeling voor een kortere of langere periode bezoeken worden oprecht bedankt woor hun interesse en stimulerende aanwezigheid.

Veel dank ben ik verschuldigd aan mijn directe medewerkers. Vanaf 1985 heb ik, samen met dr. C. de Die-Smulders, een enorme ontwikkeling mee mogen maken: de ontwilkkeling van het specialisme, de opkomst van de DNA diagnostiek, de erkenming alls opleidingsinstituut en als opleider en ga zo maar door. Christine, jouw rol in het geheel is buiten discussie groot en waardevol. Aan liedereen van de staf en aan de hele klinische groep ben ik dank werschuldigd voor de positieve sfeer waarin wij, vaak onder hoge werkdruk en onder minder aantrekkelijke ruimtelijke omstandigheden, ons werk verrichten. Deze leerstoel is een erkenning voor ons allemaal!

Op mijn tocht naar deze positie ben ik meerdere beren tegen gekomen. Tijdens mijn opleiding tot kinderarts de grootste. Beren hoeven niet per definitie een negatieve uitwerking te hebben: soms bevorderen ze de vorming van sterkere, gemotiveerde professionals, die negatieve ervaringen positief om kunnen zetten. De vele collegae die met mij toentertijd in opleiding waren en nu net als ik hoogleraar zijn, zijn hieir getuige van. Dank voor jullie steun toen en voor diegenen die hier nu zijn, dank voor jullie aanwezigheid.

Mijn ouders en schoonouders: Dank voor de niet aflatende steun aan mij als dochter, als schoondochter en als moeder van jullie kleinkinderen. Als vrouw uit een volgende generatie heb ik meer kansen gekregen en deze kunnen benutten.

Jaap, zonder jouw steun en stimulans was het nooit gelukt: samen hebben we onze carrières vorm kumnen geven met als doel vooral een goed thuisfront te hebben maar ook om onze doelgroep die wilj als "bijzondere kinderen" benoemen goed te verzorgen in de breedst mogelijke zin.

Zonder de zeer gewaardeerde ondersteuning thuis was dit niet mogelijk geweest. 
Tot slot dank aan Dirk en Anna, die mij geregeld en heel terecht voorhouden dat ook een professor dom kan zijn.

lk heb gezegd. 


\section{Literatuur}

A5PASIA geevalueerd. Mediator 2001;12:30-31.

Aylsworth A, Graham JM Jr, Hall IG, Hoyme HE, Lyons Jones KK, Stevenson RE. Clinical, natural history, and imaging information on patients included in reports. J Med Genet 2003;119A:93.

Carey JC. Response to letter: Clinical, natural history, and imaging information on patients included in reports. Am I Med Genet 2003:19A:94.

Cassidy SB, Allanson JE (eds). Management of genetic syndromes. John Wiley \& Sons, New York, 2001.

Chudley AE. Landmarks in genetics through philately: the tools used bij dysmorphologists. Clin Genet 2003;63:105-108.

Curfs $L M G$, van der Vlugt $H$. Berndsen-Peeters $\mathrm{KJ}$, Schrander-Stumpel CTRM. Neuropsychological profile in Kabuki syndrome. Genetic Counseling 2002;3:373.

Curry CI, Stevenson RE, Aughton D, Byrne J, Carey JC, Cassidy S, Cunniff C, Graham $I M$ Jr, Jones MC, Kaback MM, Moeschler J, Schaefer GB, Schwartz 5 , Tarleton J, Opitz J. Evaluation of mental retardation: recommendations of a consensus conference. Am J Med Genet 1997;72:468-477.

De Angelis CD. Women in academic medicine: new insights, same sad news.

Defloor T, Van Borsel I, Schrander-Stumpel CTRM, Curfs LMG. Articulation in Kabuki Syndrome. Cenetic Counseling 2003; in press.

Engelshoven van J. Dokter of doctor: een academisch medisch specialist kan niet alles tegellik. Medisch Contact 2002;8:285.

Evenhuis. HM. Normale burgers, bijzondere patiënten. Medisch Contact 2001:56:341-343.

Frederikkson M. Als vrouwen wijs waren. Uitgeverij De Geus by, Breda, 1999. ISBN 9044503227. 
Fryns JP. Genetic causes of mental retardation. A personal contribution. Thesis, 1986. Katholieke universiteit Leuven. 1986.

Frints S. From phenotype to genotype to phenotype. Thesis, 2002. Katholieke universiteit Leuven.

Genetic Alliance. 2002. www geneticalliance org

Gruijter M. Huisarts naast AVG: mogeijkheden en valkuilen. TVAZ $2000 ; 8: 5-6$.

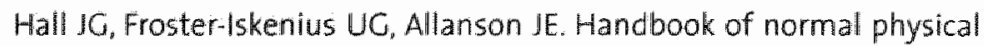
measurements.

Oxford University Press. Oxford. 1989.

Hall JG. A clinician's plea. Nature Genetics 2003:33:440-442.

Holzman NA. Are genetic tests adequately regulated? Science $1999 ; 286: 40$.

Jonkman MF, Rulo HFC, Duipmans JC. Van gen naar ziekte; epidermolysis bullosa door mutaties in eiwitten in of rond het hemidesmosoom. Ned Tijdschr Geneeskd 2003;147:1108-1113.

Koninkijke Nederlandse Academie van Wetenschappen (KNAW).The social impact of applied health research. Towards a quality assessment system. Amsterdam: KNAW: 2002.

Lagro-Janssen T. De tweeslachtigheid van het werschil. Uitgeverij SUN, Nijmegen, 1997.

Lautenbag E. Hoogleraar moet zich blijven bewijzen. 5can 2002;3:20.

Lin AE, Terry SF, Lerner $B$, Anderson $R$, Irons M. Participation by clinical geneticists in genetic adwocacy groups. Am J Med Gen 2003:119A:89-92.

Mckusick V. Mendelian inheritance in man. A catalogue of human genes and genetic disorders. 12e editie, The John Hopkins Uniwersity Press. Baltimore and Londen. 
Medisch Contact 2003;58:622. Zorgoverdracht verstandelijk gehandim capten geregeld.

OMMM on line: www.ncbintm.nih.gow/Omim

Planningsbesluit klinisch genetisch onderzoek en erfelijkheidsadvisering. WWS. Staatscourant 2003;16:11-17.

Schrander-Stumpel CTRM, van Benthem LHBM, Bijlsma IB. Het faciodigitogenitale syndroom (Aarskog-syndroom). Ned Tijdschr Geneesk $1985: 129: 684-688$.

Schrander-Stumpel CTRM. Clinical and genetic aspects of the X-linked hydrocephalus/MASA spectrum. Thesis, 1995. Rijksuniwersiteit Limburg. Maastricht.

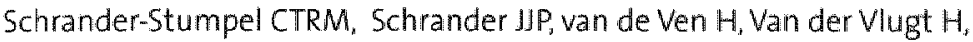
Defloor T. Curfs LMG. Kabuki syndrome: clinical features in 21 patients, literature review and guidelines for preventive management. Eur I Hum Genet 2002;10(suppl 1):115.

Schrander-Stumpel CTRM, Curfs L, Sastrowyoto P, Schrander J Cassidy S. Fryns JP. Prader-Willi syndrome: causes of death in an international series of 27 cases. Am J Med Genet 2003; in press.

Schrander-Stumpel CTRM, de Nijs Bik H. Maandelijke serie artikelen over klinische genetische onderwerpen. Patient Care maart 2000 tot juni 2003: 40 artikelen (referentielijst op aanvraag).

Science Citation Index. wrww.ub.unimaas.nl/w1/n.asp

Smeets E, Schrander-Stumpel CTRM. Rett syndrome. In: Cassidy SB, Allanson JE (eds). Management of genetic syndromes. John Wiley \& Sons, New York. ze druk, 2003, in press.

Smeets E, Moog U, Curfs L, Schollen E, Matthijs G, Herbergs d, de DieSmulders CEM, Schrander-Stumpel CTRM, Fryns JP. Rett syndrome in adult women. Am I Med Genet 2003 in press.

Takkemberg. H. Wordt de professor een mevrourw? VNVA-krant 2003;39:2-3. 
Velden van der LFJ, Heiligers. PhiM, Hingstman L. Een studie van jaren. Vertragingen in de opleiding tot arts. Medisch Contact 2003:58:694697.

Verhoef J. Academische carrière in het slop. Medisch Contact 2003:58:60.

VNVA, WWWWnva.in!

Vrouwelijke hoogleraren in Nederland. ledereen hoogleraar $\mathrm{m} / \mathrm{v}$ ? Hoogleraarschap in de eenentwintigste eeuw. Symposiumverslag InVH 2002.

VSOP. Kiezen voor kansen. VSOP meerjarenplan 2003-2005. Soestdijk, december 2002 .

VSOP: WWWwsop.nI

Weel van C. Kwaliteitsbeoordeling van medisch-wetenschappelijk onderzoek voortaan ook op grond van maatschappelijke implicaties. Ned Tijdschr Geneesk 2003:147:233-235.

Wesseling L. Geleerde moeders. ISBN 9066172657 . De Balle. Amsterdam. 2001.

Wilson GN and Cooley WC. Preventive management of children with congenital anomalies and syndromes. Cambridge University Press. Cambridge 2000. 